\title{
Antibacterial activity of Artemisia nilagirica leaf extracts against clinical and phytopathogenic bacteria
}

\author{
Abdul R Ahameethunisa, Waheeta Hopper
}

\begin{abstract}
Background: The six organic solvent extracts of Artemisia nilagirica were screened for the potential antimicrobial activity against phytopathogens and clinically important standard reference bacterial strains.

Methods: The agar disk diffusion method was used to study the antibacterial activity of A. nilagirica extracts against 15 bacterial strains. The Minimum Inhibitory Concentration (MIC) of the plant extracts were tested using two fold agar dilution method at concentrations ranging from 32 to $512 \mu \mathrm{g} / \mathrm{ml}$. The phytochemical screening of extracts was carried out for major phytochemical derivatives in A. nilagirica.

Results: All the extracts showed inhibitory activity for gram-positive and gram-negative bacteria except for Klebsiella pneumoniae, Enterococcus faecalis and Staphylococcus aureus. The hexane extract was found to be effective against all phytopathogens with low MIC of $32 \mu \mathrm{g} / \mathrm{ml}$ and the methanol extract exhibited a higher inhibition activity against Escherichia coli, Yersinia enterocolitica, Salmonella typhi, Enterobacter aerogenes, Proteus vulgaris, Pseudomonas aeruginosa $(32 \mu \mathrm{g} / \mathrm{ml})$, Bacillus subtilis $(64 \mu \mathrm{g} / \mathrm{ml})$ and Shigella flaxneri $(128 \mu \mathrm{g} / \mathrm{ml})$. The phytochemical screening of extracts answered for the major derivative of alkaloids, amino acids, flavonoids, phenol, quinines, tannins and terpenoids.

Conclusion: All the extracts showed antibacterial activity against the tested strains. Of all, methanol and hexane extracts showed high inhibition against clinical and phytopathogens, respectively. The results also indicate the presence of major phytochemical derivatives in the A. nilagirica extracts. Hence, the isolation and purification of therapeutic potential compounds from A. nilagirica could be used as an effective source against bacterial diseases in human and plants.
\end{abstract}

\section{Background}

Artemisia is one of the diverse genera of Asteraceae family with many important medicinally valuable essential oils and secondary metabolites. Essential oils of Artemisia spp. have been widely used for a variety of medicinal purposes for many years. Artemisia nilagirica (Clarke) pamp commonly called Indian wormwood, is widely found in the hilly areas of India. A. nilagirica has been reported to exhibit insecticidal activities [1]. Around 59 compounds were identified from essential oil of $A$. nilagirica which showed an inhibitory activity on Phytophthora capsici, causing "foot rot" in pepper [2].

\footnotetext{
* Correspondence: bioinforesearch2009@gmail.com
Department of Bioinformatics, School of Bioengineering, SRM University,

* Correspondence: bioinforesearch2009@gmail.com
Department of Bioinformatics, School of Bioengineering, SRM University, Kattankulathur, Tamil Nadu, India
}

(c) 2010 Ahameethunisa and Hopper; licensee BioMed Central Ltd. This is an Open Access article distributed under the terms of the Creative Commons Attribution License (http://creativecommons.org/licenses/by/2.0), which permits unrestricted use, distribution, and reproduction in any medium, provided the original work is properly cited. for their biological activities. It is considered to produce most medicinally important secondary metabolites [3,4]. Several interesting studies using Artemisia spp. showed a series of antimicrobial and antioxidant activities [5-9]. The qualitative determination of various secondary metabolites like flavonoids, terpenoids, saponins and polysaccharides of Artemisia spp. were detected by HPLC, GC-MS and NMR [10,11]. Few considerable secondary metabolites were successfully isolated and used in food industry as an alternative to synthetic antimicrobials [12,13]. Furthermore, extracts of Artemisia spp. were used as natural pesticide and also in the treatment of few human diseases [14-17]. The determination of potential antimicrobial activity of Artemisia nilagirica extracts could be more informative for the future use in 
controlling phytopathogens and also in clinical treatment as natural antimicrobial agents.

The organisms like Escherichia, Enterobacter, Klebsiella, Proteus, Shigella and Staphylococcus species are implicated to cause severe infections in human, as they are found in multiple environmental habitats $[18,19]$. Erwinia spp., Clavibacter michiganense, Pseudomonas syringae and Xanthomonas campestris were reported to be severe phytopathogens, causing damage in carrot, potato, tomato, leafy greens, onion, green pepper, squash and other cucurbits. Furthermore, these phytopathogens cause disease in any plant tissue it invades [20].

In the present study, the antimicrobial potency of chloroform, diethyl ether, ethanol, hexane, methanol and petroleum ether extracts of Artemisia nilagirica was investigated. The antibacterial activity was determined by disk diffusion method and minimum inhibitory concentration (MIC) test. Four plant pathogens and 11 clinically important CLSI [21] reference bacterial strains from American Type Culture Collection (ATCC), Microbial Type Culture Collection (MTCC) and a local isolate from SPIC Science Foundation Patholab (SSFP) were used as test cultures. The preliminary phytochemical screening was carried out to identify the derivatives in the extracts.

\section{Methods}

Plant material and extraction

Fresh leaves of Artemisia nilagirica were collected from Nilgiri district, Tamil Nadu, India. Plant leaves were cleaned with deionized water and dried at shade for a week. Blotted leaves were grounded and filtered using four layers of gauss cloth. The plant powder was stored in air tight container and maintained at $4^{\circ} \mathrm{C}$ until use.

Solvent systems used for the extractions were chloroform, diethyl ether, ethanol, hexane, methanol and petroleum ether. Soxhlet and flask extraction procedures were adapted for extraction. Ten grams of the powered samples were packed in muslin cloth and used for extraction by soxhlet apparatus at a temperature below the boiling temperature of each solvent. A portion of the powdered plant samples was soaked in the conical flask containing solvent, wrapped with aluminum foil and placed in shaker for 48 hours at 120-130 rpm.

After 48 hours, the extracts were filtered using Whatman filter paper No: 1. The solvent was evaporated and the residue was dissolved in sterile dimethylsulfoxide (DMSO-9:1) in $50 \mathrm{mg} / \mathrm{ml}$ concentration. The extract was filtered using 0.22 micro filter (Type GV- Millipore) and stored at $4^{\circ} \mathrm{C}$ for further antimicrobial activity study. Test microorganisms

The 15 bacterial cultures of both gram-positive and gram-negative bacterial strains used for screening are:
Erwinia sp. (MTCC 2760), Xanthomonas campestris (MTCC 2286), Pseudomonas syringae (ATCC 7386), Clavibacter michiganense (ATCC 27822), Escherichia coli (ATCC 25922), Yersinia enterocolitica (MTCC 840), Klebsiella pneumoniae (ATCC 15380), Salmonella typhi (SSFP 4S), Enterobacter aerogenes (MTCC 111), Proteus vulgaris (MTCC 1771), Pseudomonas aeruginosa (ATCC 27853), Shigella flaxneri (MTCC 1457), Bacillus subtilis (MTCC 441), Enterococcus faecalis (ATCC 29212) and Staphylococcus aureus (MTCC 29212). The stock cultures were maintained in nutrient agar (NA) slant at $4^{\circ} \mathrm{C}$ and sub-cultured monthly. Working cultures were prepared by inoculating a loopful of each test microorganism in $3 \mathrm{ml}$ of nutrient broth (NB) from NA slants. Broths were incubated at $37^{\circ} \mathrm{C}$ for 12 hours. The suspension was diluted with sterile distilled water to obtain approximately $10^{6} \mathrm{CFU} / \mathrm{ml}$.

\section{Screening for antibacterial activity}

Disk diffusion: $5 \mathrm{~mm}$ of sterile disks were incorporated in $100 \mu \mathrm{l}$ of plant extracts ( $5 \mathrm{mg} /$ disk). The disk was completely saturated with the extract and allowed to dry. Mueller Hinton (MH) agar plates were swabbed with test bacteria and six extract disks with one of the standard positive control disks (ampicillin, streptomycin or gentamycin) was placed on the $\mathrm{MH}$ agar plate. DMSO was taken as the negative control. Plates were incubated overnight at $37^{\circ} \mathrm{C}$.

\section{Agar dilution susceptibility test}

The agar dilution susceptibility test was performed based on modified method of NCCLS and CLSI [22,23] to determine the MIC. Extracts dissolved in sterilized DMSO $(5120 \mu \mathrm{g} / \mathrm{ml}$ concentration) were taken as standard stock. A series of two fold dilutions of each extract in the final concentration of 512, 256, 128, 64 and 32 $\mu \mathrm{g} / \mathrm{ml}$ were prepared in $\mathrm{MH}$ agar. After solidification, the plates were spotted with $2 \mu$ l of overnight grown bacterial cultures approximately containing $1 \times 10^{4}$ $\mathrm{CFU} / \mathrm{ml}$. The test was carried out in triplicates. The plates were incubated overnight at $37^{\circ} \mathrm{C}$. After $18-24$ hours, the MIC was determined and the percentage of growth inhibition was calculated by,

$$
\text { Percentage of inhibition }(\mathrm{Pi})=\frac{\mathrm{T}-\mathrm{SC}}{\mathrm{PC}} \times 100
$$

T: Test: SC: Solvent control; PC: positive control Phytochemical screening

To identify the phytochemical derivatives in the extracts, standard phytochemical screening was performed $[24,25]$. Alkaloids test was performed by Dragendorff's and Meyer's tests, amino acids by ninhydrin, carbohydrates by Barfoed's and Fehling tests, flavonoids by $\mathrm{FeCl}_{3}$, Pew's and Shinoda's tests, glycosides by KillerKillanis test, saponin by frothing test, tannins by $\mathrm{FeCl}_{3}$ 
Table 1 Antibacterial activity screening of $A$. nilagirica by disk diffusion

\begin{tabular}{|c|c|c|c|c|c|c|c|c|}
\hline \multirow[b]{2}{*}{ Bacterial culture } & \multicolumn{8}{|c|}{ Zone of inhibition ( $\mathrm{mm}$ diameter) } \\
\hline & Positive control & Solvent control & Ethanol & Methanol & Hexane & Petroleum Ether & Chloroform & Diethyl ether \\
\hline Erwinia sp. & 15 & - & $10 \pm 0.0$ & $12 \pm 0.5$ & $13 \pm 1.0$ & $10 \pm 0.0$ & $12 \pm 0.0$ & $10 \pm 0.5$ \\
\hline X. campestris & 16 & - & $11 \pm 0.5$ & $12 \pm 0.0$ & $14 \pm 0.0$ & $11 \pm 0.5$ & $12 \pm 0.1$ & $11 \pm 0.5$ \\
\hline P. syringae & 14 & - & $11.8 \pm 0.5$ & $11 \pm 0.0$ & $12 \pm 0.0$ & $10 \pm 0.0$ & $10 \pm 0.0$ & $12 \pm 0.5$ \\
\hline C. michiganense & 15 & - & $12 \pm 1.0$ & $12 \pm 0.0$ & $13 \pm 0.0$ & $8 \pm 0.0$ & $11 \pm 0.0$ & $12.4 \pm 0.5$ \\
\hline E. coli & 13 & - & $14 \pm 1.0$ & $12 \pm 0.5$ & $8 \pm 0.0$ & $8 \pm 0.0$ & $11 \pm 0.5$ & $11 \pm 0.0$ \\
\hline Y. enterocolitica & 14 & - & $11 \pm 1.0$ & $12 \pm 0.0$ & $11 \pm 0.0$ & $9 \pm 0.5$ & $13 \pm 0.0$ & $14 \pm 0.0$ \\
\hline B. subtilis & 13 & - & $8 \pm 0.0$ & $8 \pm 0.0$ & - & $8 \pm 0.0$ & $10 \pm 0.0$ & $10 \pm 0.0$ \\
\hline E. faccalis & 14 & - & - & - & - & - & $7 \pm 0.0$ & $8 \pm 0.0$ \\
\hline K. pneumonia & 12 & - & - & $8 \pm 0.0$ & - & - & - & - \\
\hline S. typhi & 10 & - & $8 \pm 0.0$ & $10 \pm 0.0$ & $13 \pm 1.0$ & $12 \pm 1.0$ & $8 \pm 0.0$ & $8 \pm 0.0$ \\
\hline S. aureus & 12 & - & - & - & - & - & $7 \pm 0.0$ & - \\
\hline E. acrogens & 14 & - & $8 \pm 0.0$ & $11 \pm 1.0$ & $8 \pm 0.0$ & $8 \pm 0.0$ & $10 \pm 0.0$ & $8 \pm 0.5$ \\
\hline P. valgaris & 14 & - & $8 \pm 0.0$ & $12 \pm 1.0$ & $14 \pm 0.0$ & $14 \pm 0.5$ & $10 \pm 0.0$ & $8 \pm 0.0$ \\
\hline P. aeruginosa & 13 & - & $10 \pm 0.0$ & $12 \pm 0.0$ & $13 \pm 0.0$ & $12 \pm 0.0$ & $10 \pm 0.0$ & $8 \pm 0.0$ \\
\hline S. flexneri & 14 & - & $8 \pm 0.0$ & $10 \pm 1.0$ & $8 \pm 0.0$ & $8 \pm 0.0$ & $10 \pm 0.0$ & $8 \pm 0.0$ \\
\hline
\end{tabular}

\pm - mean standard deviation of triplicates, Concentration of extract- $5 \mathrm{mg} /$ disk, (-) - No zone of inhibition observed, Positive controls - ampicillin or streptomycin or gentamycin $(10 \mu \mathrm{g} / \mathrm{ml})$, Solvent control - $10 \%$ DMSO.

and lead acetate \& terpenoids by Salkowski test. The test for hydrolysable tannins, phlobatannins, phenol, quinones and volatile oils were also carried out as in literature [26-28].

\section{Statistical analysis}

Analysis of variance (ANOVA) was performed using GeneSpring GX - 7.3 microarray software to determine the significance of MIC values between the extracts against bacterial culture. The probability value $(\mathrm{p}) \leq$ 0.05 was considered as significance in this study.

\section{Results \& Discussion}

The antibacterial activity of $A$. nilagirica leaf extracts were examined against 11 clinical and four phytopathogens causing illness in human and damage in major crops [20], respectively. The extractions were carried out using chloroform, diethyl ether, ethanol, hexane, methanol and petroleum ether solvents. The ethanol and methanol extracts gave the high yield of $2.3 \%$ (\% concentration $\mathrm{w} / \mathrm{v}$ ) and hexane gave $1.6 \% \mathrm{w} / \mathrm{v}$. While, other extracts provide much low yield of $0.6 \% \mathrm{w} / \mathrm{v}$ in soxhlet and flask extraction procedures. The antibacterial activity of the organic solvent extracts showed varying magnitudes of inhibition patterns with standard positive control depending on the susceptibility of the tested microorganism. Out of 15 bacterial strains tested, 12 showed inhibition activity to one or more extracts. The mean inhibitory zone of six solvent extracts against 15 bacterial species is summarized in Table 1.

The analysis of methanol and chloroform extracts against phytopathogens showed a significant level of inhibition against Erwinia sp. and X. campestris. On the other hand, ethanol and diethyl ether extracts showed high activity against $C$. michiganense and P. syringae ( $\mathrm{p}$ $\leq 0.05$ ). Also, the petroleum ether extracts showed 11$12 \mathrm{~mm}$ zone of inhibition to $C$. michiganense. Interestingly, hexane extract of $A$. nilagirica exhibits maximum inhibitory activity against all the phytopathogens in comparison to other extracts [Table 1]. Further, hexane extracts showed the significant inhibitory effect against Clavibacter michiganense $(13 \mathrm{~mm})$, Erwinia sp $(13 \mathrm{~mm})$, Pseudomonas syringae $(12 \mathrm{~mm})$ and Xanthomonas campestris $(14 \mathrm{~mm})$. It is understandable that hexane extract is more potent showing a higher degree of antimicrobial activity to phytopathogens in comparison to other extracts. Also, the results of hexane extract against $X$. campestris was appeared to be two-fold better than the previous study of Phyllanthus emblica, Acacia nilotica, Sapindus mukorossi and Terminalia chebula which shows $6.00 \mathrm{~mm}$ zone of inhibition at $50 \mathrm{gm} / \mathrm{l}$ concentration reported as the most effective for $X$. campestris [29]. In addition, moderate effects were seen in chloroform, diethyl ether, ethanol and methanol extracts against all tested phytopathogens except petroleum ether which showed comparatively minimum area of inhibition. This possibly means that the compound responsible for the antibacterial activity was least in concentration.

Similar analysis of $A$. nilagirica leaf extracts were carried out on clinical bacterial pathogens. The hexane, methanol and petroleum ether extracts exhibited significant high inhibitory zones against $P$. aeruginosa, $P$. vulgaris and S. typhi. The chloroform and diethyl ether extracts showed maximum area zone of inhibition (10 
Table 2 Minimum inhibitory concentration (MIC) of various solvent extracts of $A$. nilagirica (\% v/v) against microorganisms

\begin{tabular}{|c|c|c|c|c|c|c|c|}
\hline \multirow[t]{2}{*}{ Test organism } & \multicolumn{7}{|c|}{ Plant extracts } \\
\hline & & Chloroform & Diethyl ether & Ethanol & Hexane & Methanol & Petroleum ether \\
\hline & & \multicolumn{6}{|c|}{ Concentration $(\mu \mathrm{g} / \mathrm{ml})$ showing Minimum inhibitor concentration } \\
\hline Erwinia sp. & Phytopathogens & 32 & 64 & 64 & 32 & 64 & 64 \\
\hline Xanthomonas campestris & & 32 & 64 & 32 & 32 & 32 & 128 \\
\hline Pseudomonas syringae & & 64 & 32 & 128 & 32 & 64 & 64 \\
\hline Clavibacter michiganense & & 128 & 32 & 32 & 32 & 32 & 32 \\
\hline Escherichia coli & Clinical pathogens & 256 & 256 & 32 & 256 & 32 & 128 \\
\hline Yersinia enterocolitica & & 64 & 256 & 128 & 128 & 32 & 512 \\
\hline Basillus subtilis & & 32 & 32 & 32 & 32 & 64 & 32 \\
\hline Enterococcus faccalis & & * & * & * & $*$ & 512 & $*$ \\
\hline Klebsiella pnumonia & & * & * & * & * & * & ${ }^{*}$ \\
\hline Salmonella typhi & & 32 & 64 & 128 & 64 & 32 & 32 \\
\hline Staphylococcus aureus & & * & * & * & 512 & * & * \\
\hline Entrobacter acrogens & & 512 & 128 & 32 & 128 & 32 & 32 \\
\hline Proteus valgaris & & 32 & 256 & 128 & 32 & 32 & 64 \\
\hline Pseudomonas aeruginosa & & 512 & 128 & 128 & 128 & 32 & 512 \\
\hline Shigella flexneri & & 512 & 256 & 256 & 256 & 128 & 128 \\
\hline
\end{tabular}

* No inhibition observed upto: $512 \mu \mathrm{g} / \mathrm{ml}$.

$\mathrm{mm})$ for B. subtilis, compared to other extracts $(8 \mathrm{~mm})$. The ethanol extract exhibited $14 \mathrm{~mm}$ zone for E. coli, which is the maximum with respect to the positive standard streptomycin. Subsequently, antibacterial activity of methanol $(12 \mathrm{~mm})$, chloroform $(13 \mathrm{~mm})$ and diethyl ether $(14 \mathrm{~mm})$ extracts were found as effective for $Y$. enterocolitica. Moderate activities were observed against $S$. flexneri and E. aerogenes for chloroform and methanol extracts. Among the 11 clinical bacterial strains, Escherichia coli, Yersinia enterocolitica, Bacillus subtilis, Salmonella typhi, Enterobacter aerogenes, Proteus vulgaris, Pseudomonas aeruginosa and Shigella flexneri were the most susceptible bacteria to all solvent extracts. Nearly, $40 \%$ growth inhibitions were observed in concentration of $5 \mathrm{mg} / \mathrm{ml}$. Surprisingly, no activity were observed against $S$. aureus, E. faecalis and $K$. pneumoniae suggesting their resistance to $A$. nilagirica extracts.

The MIC tests of $A$. nilagirica organic solvent extracts against 15 bacterial species were carried out using the micro dilution technique. The MIC values of 6 extracts ranged from 32 to $512 \mu \mathrm{g} / \mathrm{ml}$ [Table 2]. While considering phytopathogens, chloroform extract showed maximum activity with MIC $32 \mu \mathrm{g} / \mathrm{ml}$ for Erwinia sp. and $X$. campestris. Diethyl ether extracts showed $32 \mu \mathrm{g} / \mathrm{ml} \mathrm{MIC}$ for P. syringae and C.michiganense. In general, all extracts showed less than $128 \mu \mathrm{g} / \mathrm{ml}$ MIC for the tested phytopathogens. Interestingly, hexane extract had higher activity in all the phytopathogens even at a low concentration of $32 \mu \mathrm{g} / \mathrm{ml}$. The MIC analysis of clinical pathogens showed that the methanol extract was highly active in comparison to other extracts, which inhibited the series of study organisms at a low concentration $(32 \mu \mathrm{g} / \mathrm{ml})$ except B. subtilis $(64 \mu \mathrm{g} / \mathrm{ml})$ and Shigella flexneri $(128$ $\mu \mathrm{g} / \mathrm{ml}$ ) [Table 2]. In supportive to the susceptible test, $A$. nilagirica extracts had very low or no activity, even in the highest concentration $(512 \mu \mathrm{g} / \mathrm{ml}) \mathrm{MIC}$ against $S$. aureus, E. faecalis and K. pneumoniae. Hence, we conclude that these organisms are resistant to A. nilagirica extracts. According to the results from zone of inhibition and MIC studies [Table $1 \& 2$ ], hexane and methanol extracts are considerably good inhibitors for the phytopathogens and clinical pathogenic bacteria, respectively.

Phytochemical test were carried out on the A. nilagirica extracts to determine the natural bioactive compound. By studying the presence of phytochemical in $A$. nilagirica, the medicinal value of the plant can be explained scientifically. The phytochemical screening of extracts showed the presence of major derivatives and their results were summarized [Table 3]. The analysis showed the occurrence of alkaloids, flavonoids, phenol, quinines and terpenoids in all extracts. Tannins were present in ethanol, methanol and diethyl ether. Volatile oils were present in methanol, hexane and petroleum ether. Phlobatannins metabolites were found to be present in hexane and petroleum ether and absent in other extracts. Also, saponins and amino acid were present in ethanol and methanol extracts with carbohydrates particularly present in methanol extract. Surprisingly, glycosides and hydrolysable tannins were absent in all the extracts. 
Table 3 Phytochemical screening of $A$. nilagirica extracts

\begin{tabular}{|c|c|c|c|c|c|c|c|}
\hline S. no. & Test & Chloroform & Diethyl ether & Ethanol & Hexane & Methanol & Petroleum ether \\
\hline 1 & Alkaloids & ++ & ++ & ++ & ++ & ++ & + \\
\hline 2 & Amino acids & - & - & + & - & ++ & - \\
\hline 3 & Carbohydrates & - & - & - & - & + & - \\
\hline 4 & Flavonoids & ++ & + & ++ & ++ & ++ & + \\
\hline 5 & Glycosides & - & - & - & - & - & - \\
\hline 6 & Hydrolysable tannins & - & - & - & - & - & - \\
\hline 7 & Phenol & ++ & + & ++ & + & ++ & + \\
\hline 8 & Phlobatannins & - & - & - & + & - & + \\
\hline 9 & Quinines & + & + & + & + & + & + \\
\hline 10 & Saponin & - & - & + & - & + & - \\
\hline 11 & Tannins & - & + & ++ & - & ++ & - \\
\hline 12 & Terpenoids & ++ & ++ & ++ & ++ & ++ & ++ \\
\hline 13 & Volatile oils & - & - & - & + & + & - \\
\hline
\end{tabular}

$(++)$ abundant, (+) present, (-) absent

In susceptibility test, the hexane extracts showed the considerable levels of inhibition against phytopathogens. The phytopathogens test of petroleum ether extract showed low inhibition range ( 8 to $10 \mathrm{~mm}$ ) in comparison to other extracts (10 to $14 \mathrm{~mm}$ ). In conjugation with phytochemical screening of all the extracts with petroleum ether, showed the variations in abundance in alkaloids derivates. Hence, it is suggested that reduction of alkaloid abundance in petroleum ether may be the cause of decreased activity in phytopathogens. Supportive to our finding, previous studies indicate the effective role of alkaloid against phytopathogens [30-32]. The MIC analyses of clinical pathogens showed an activity against Gram-positive and Gram-negative bacteria may be indicative of the presence of the broad spectrum antibiotic compounds. The methanol extracts showed high inhibition at the minimal concentration for most of the clinical pathogens in comparison to other extracts. The MIC value of methanol extract ranges from 32 to $64 \mu \mathrm{g} / \mathrm{ml}$ for Escherichia coli, Bacillus subtilis, Yersinia enterocolitica, Salmonella typhi, Enterobacter aerogenes, Proteus vulgaris and Pseudomonas aeruginosa. Also, the phytochemical screening of menthol extract showed the presence of most of the derivatives like flavonoids, terpenoids, phenol, amino acids, alkaloids and tannins. Furthermore, alkaloids [33,34], amino acids [35], flavonoids [36-38], phenols [39], tannins [40-42], terpenoids [43] of various plants extracts proven to be effective antimicrobials [44]. Our results are also in agreement with these studies suggesting the efficacy of methanol extract of $A$. nilagirica against clinical pathogens.

\section{Conclusion}

Extracts of A. nilagirica showed the broad spectrum of antibacterial activity on the tested microorganisms. Hexane extract exhibited high inhibitory potency against phytopathogens and methanol extract showed maximum inhibition against clinical pathogens except $S$. aureus, $E$. faecalis and K. pneumoniae. The phytochemical analysis showed the presence of effective biological compounds like alkaloids, amino acids, flavonoids, phenols, tannins and terpenoids. These derivatives could be potential alternatives to the traditional chemical control of clinical pathogen and phytopathogenic bacteria. Furthermore, the development of natural antimicrobials will help to decrease the negative effects of synthetic drugs. Fractionation and characterization of these active compounds will be the future work to investigate.

\section{Acknowledgements}

We thank Dr. Murugesh KA, Assistant professor, Horticultural Research Station, Udhagamandalam, India, for the collection of the plant.

Ahameethunisa thank, SRM University for financial support.

\section{Authors' contributions}

AA has carried out the experimental part such as extraction, inoculums preparation and antimicrobial evaluation. WH supervised the work, evaluated the results and corrected the manuscript for publication. Authors read and approved the final manuscript.

Competing interests

The authors declare that they have no competing interests.

Received: 23 July 2009

Accepted: 29 January 2010 Published: 29 January 2010

\section{References}

1. Banerji A, Luthriya DL, Kokate SD: Toxicity of capillin, the insecticidal principle of Artemisia nilagirica Clarke. Indian J Exp Biol 1990, 28:588-589.

2. Shafi PM, Nambiar MKG, Clery RA, Sarma YR, Veena SS: Composition and antifungal activity of the oil of Artemisia nilagirica (Clarke) Pamp. JEOR 2004, 16:377-379.

3. Ambasta SP: The useful plants of India. Publications \& Information Directorate. CSIR, New Delhi 1986, 55-56.

4. Priscila IU, Mariama TNS, Luiz CDS, Luciano B, Fernandes AJ: Antibacterial activity of medicinal plant extracts. Braz J Microbiol 2007, 38:717-719.

5. Juteau F, Masotti V, Bessiere JM, Dherbomez M, Viano J: Antibacterial and antioxidant activities of Artemisia annua essential oi I. Fitoterapia 2002, 73:532-535. 
6. Kordali S, Kotan R, Mavi A, Cakir A, Ala A, Yildirim A: Determination of the Chemical Composition and Antioxidant Activity of the Essential Oil of Artemisia dracunculus and of the Antifungal and Antibacterial Activities of Turkish Artemisia absinthium, A. dracunculus, Artemisia santonicum, and Artemisia spicigera Essential Oils. J Agric Food Chem 2005, 53:9452-9458.

7. Kordali S, Cakir A, Mavi A, Kilic H, Yildirim A: Screening of chemical composition and antifungal and antioxidant activities of the essential oils from three turkish Artemisia Species. J Agric Food Chem 2005, 53:1408-1416.

8. Curini M, Epifano F, Genovese S, Tammaro F, Menghini L: Composition and antimicrobial activity of the essential oil of Artemisia dracunculus "piemontese" from italy. Chem Nat Comp 2006, 42:738-740.

9. Cha JD, Jung EK, Kil BS, Lee KY: Chemical composition and antibacterial activity of essential oil from Artemisia feddei. J Microbiol Biotechnol 2007, 17:2061-2065

10. Xie G, Schepetkin IA, Siemsen DW, Kirpotina LN, Wiley JA, Quinn MT: Fractionation and Characterization of Biologically-active Polysaccharides from Artemisia tripartite. Phytochemistry 2008, 69:1359-1371.

11. Avula B, Wang YH, Smillie TJ. Mabusela W, Vincent L, Weitz F, Khan IA: Quantitative determination of flavonoids by column high-performance liquid chromatography with mass spectrometry and ultraviolet absorption detection in Artemisia afar and comparative studies with various species of Artemisia plants. J AOAC Int 2009, 92:633-44.

12. Ng TB: Antifungal proteins and peptides of leguminous and nonleguminous origins. Peptides 2004, 25:1215-22.

13. Pattison LT, Lindsay D, von Holy A: Natural antimicrobial as potential replacements for calcium propionate in bread. S Afr J Sci 2004, 100:339-342.

14. Mueller MS, Karhagomba IB, Hirt HM, Wemakor E: The potential of Artemisia annua $\mathrm{L}$. as a locally produced remedy for malaria in the tropics: agricultural, chemical and clinical aspects. J Ethnopharmacol 2000 73:487-493,

15. Rahman AF, Saleh MA: Nematicidal activity of phytochemicals from some arid land plants. Society of nematlogists $45^{\text {th }}$ annual meeting, Lihue, Hawaii. J Nematol 2006, 38:258-303.

16. Saddi M, Sanna A, Cottiglia F, Chisu L, Casu L, Bonsignore L, De Logu A: Antiherpevirus activity of Artemisia arborescens essential oil and inhibition of lateral diffusion in Vero cells. Ann Clin Microbiol Antimicrob 2007, 6:10

17. Meneses R, Ocazionez RE, Martínez JR, Stashenko EE: Inhibitory effect of essential oils obtained from plants grown in Colombia on yellow fever virus replication in vitro. Ann Clin Microbiol Antimicrob 2009, 8:8.

18. Emori TG, Gaynes RP: An overview of nosocomial infections, including the role of the microbiology laboratory. Cllin microbiol Rev 1993, 6:428-442.

19. Maleki S, Seyyednejad SM, Damabi NM, Motamedi H: Antibacterial activity of the fruits of Iranian torilis leptophylla against some clinical pathogens. Pak J Biol sci 2008, 11:1286-1289.

20. Setubal JC, Moreira LM, da Silva AC: Bacterial phytopathogens and genome science. Curr Opin Microbiol 2005, 8:595-600.

21. Clinical and Laboratory Standards Institute (CLSI): Performance standards for antimicrobial susceptibility testing. Eighteenth informational supplement CLSI document M100-S18, Wayne, PA, USA 2008

22. National Committee for Clinical Laboratory Standards (NCCLS): Methods for dilution antimicrobial susceptibility tests for bacteria that grow aerobically. Approved Standard - NCCLS document M7-A6, Wayne, PA, USA , Sixth 2003.

23. Clinical and Laboratory Standards Institute (CLSI): Method for dilution antimicrobial susceptibility tests for bacterial that grow aerobically; approved standard - Eighth Edition. CLSI document M07-A8, Wayne, PA, USA 2009.

24. Harborne JB: Phytochemical methods: a guide to modern techniques of plant analysis. London, Chapman and Hall, Ltd, 2 1973, 49-188.

25. Trease GE, Evans WC: Orders and familys of plant in pharmacognosy. Oxford University Press 1983, 12:343-383.

26. Sofowora A: Recent trends in research into African medicinal plants. Ethnopharmacol 1993, 38(2-3):209-214.

27. Sofowora A: Research on Medicinal Plants and Traditional Medicine in Africa. J Altern Complement Med 1996, 2:365-372.
28. Krishnaiah D, Devi T, Bono A. Sarbatly R: Studies on phytochemical constituents of six Malaysian medicinal plants. J Med Plants Res 2009, 3:067-072.

29. Akhtar MA, Rahber-Bhatti MH, Aslam M: Antibacterial activity of plant diffusate against Xanthomonas campestris PV. Citri. Int J Pest Manag 1997, 43:149-153.

30. Torres YR, Berlinck RGS, Nascimento GGF, Fortier SC, Pessoa C, de Moraes MO: Antibacterial activity against resistant bacteria and cytotoxicity of four alkaloid toxins isolated from the marine sponge Arenosclera brasiliensis. Toxicon 2002, 40:885-891.

31. Raghavendra MP, Sathis S, Raveesha Ka: In vitro antibacterial potential of alkaloids of Samanea saman (Jacq.) merr. Against Xanthomonas and human pathogenic bacteria. World J Agric Sci 2008, 4:101-105.

32. Urgeova E, Polivka L: Secondary metabolites with antibacterial effects from leaves of different hop cultivars during vegetal periods. Nova Biotechnologica 2009, 9:327-332.

33. Shaheen F, Khan RA, Soobia A, Khan SA, Saima T, Aqeel A: New antimicrobial alkaloids from the roots of Polyalthia longifolia var. pendula. Planta medica 2003, 69:350-355.

34. Chakraborty A, Brantner AH: Antibacterial steroid alkaloids from the stem bark of Holarrhena pubescens. villosum leaves. J Ethnopharmacol 1999, 68:339-344.

35. Chowdhury N, Laskar S, Chandra G: Mosquito larvicidal and antimicrobial activity of protein of Solanum. BMC Compl Alt Med 2008, 8:62-67.

36. Brandao MGL, Krettli AU, Soares LSR, Nery CGC, Marinuzzi HC: Antimalarial activity of extracts and fractions from Bidens pilosa and other Bidens species (Asteraceae) correlated with the presence of acetylene and flavonoids compounds. J Ethnopharmacol 1997, 57:131-138.

37. Hernandez NE, Tereschuk ML, Abdala LR: Antimicrobial activity of flavonoids in medicinal plants from Tafi Del Valle (Tucuman, Argentina). J Ethnopharmacol 2000, 73:317-322.

38. Mendoza L, Wilkens M, Urzua A: Antimicrobial study of the resinous exudates and of diterpenoids and flavonoids isolated from some Chilean Pseudognaphalium (Asteraceae). J Ethnopharmacol 1997, 58:85-88.

39. Fernandez MA, Garcia MD, Saenz MT: Antibacterial activity of the phenolic acids fractions of Scrophularia frutescens and Scrophularia sambucifolia. J Ethnopharmacol 1996, 53:11-14.

40. Akiyama H, Fujii K, Yamasaki O, Oono T, Iwatsuki K: Antibacterial action of several tannins against Staphylococcus aureus. J Antimicrob Chemother 2001, 48:487-491.

41. Doss A, Mubarack MH, Dhanabalan R: Antibacterial activity of tannins from the leaves of Solanum trilobatum Linn. Indian J Sci Technol 2009, 2:41-43.

42. Amarowicz R, Dykes GA, Pegg RB: Antibacterial activity of tannin constituents from Phaseolus vulgaris, Fagoypyrum esculentum, Corylus avellana and Juglans nigra. Fitoterapia 2008, 79:217-219.

43. Amaral JA, Ekins A, Richards SR, Knowles R: Effect of selected monoterpenes on methane oxidation, denitrification, and aerobic metabolism by bacteria in pure culture. Appl Environ Microbiol 1998, 64:520-525.

44. Cowan MM: Plant Products as Antimicrobial Agents. Clin Microbiol Rev 1999, 12:564-582.

Pre-publication history

The pre-publication history for this paper can be accessed here:http://www. biomedcentral.com/1472-6882/10/6/prepub

doi:10.1186/1472-6882-10-6

Cite this article as: Ahameethunisa and Hopper: Antibacterial activity of Artemisia nilagirica leaf extracts against clinical and phytopathogenic bacteria. BMC Complementary and Alternative Medicine 2010 10:6. 